\title{
ONCHOCERCIASIS, A POSSIBLE ETIOLOGY OF ELEPHANTIASIS IN SOUTH-WEST ETHIOPIA
}

\author{
Teferra Wonde ${ }^{1}$, Isao TAdA $^{2}$ and Isao Iwamoto 3 \\ Received for publication 19 July 1973
}

\begin{abstract}
A comparative study on dermal tissue and enlarged inguinal lymph nodes from subjects infected with $O$. volvulus is presented and the histo-pathological findings are discussed. The present data indicate that there could be causal relationship between onchocerciasis and elephantiasis in South-west Ethiopia, endemic focus of the onchocercal disease. The authors drew particular attention to the non-filarial etiology reported by other investigators in Ethiopia and assessed the two contradicting views known as the nonfilarial and filarial etiology of elephantiasis.
\end{abstract}

It is a well established fact that onchocerciasis is endemic in South-west Ethiopia (Cohen, 1960, Oomen, 1969, Iwamoto et al, 1972 and Tada et al, 1972). The authors observed many cases of elephantiasis, in particular that of the lower legs, in people suffering from onchocerciasis. Although Oomen (1969), Price (1972) and Heather and Price (1972) concluded that in Ethiopia filarial infection could not be the cause of elephantiasis, the present authors tried to investigate the possible causal relationship between onchocerciasis and elephantiasis. Then the inguinal and femoral lymph nodes of many people whose skin-snips released $O$. volvulus microfilariae were found palpable and quite often enlarged in most cases. In this paper, the histo-pathological findings of the dermis and inguinal lymph nodes containing onchocercal microfilariae are presented and onchocerciasis as a potential etiology of elephantiasis is discussed.

\section{Materials And Methods}

Enlarged inguinal lymph nodes were taken from 10 subjects whose skin snips from the buttocks and legs freed numerous onchocercal microfilariae. Inguinal nodes from affected limbs 6 , palpable inguinal lymph nodes from clinically normal scrotum and limbs 3, and one inguinal node from a patient with scrotal elephantiasis. All surgically removed inguinal nodes were fixed in $10 \%$ formalin, embedded in paraffin

1 Dept. of Medical Zoology, Imperial Central Laboratory \& Research Institute, Addis Ababa, Ethiopia. 2 Dept. of Medical Zoology, Faculty of Medicine, Kagoshima University, Kagoshima, Japan (Present address: Dept. of Medical Zoology, Kanazawa Medical University, Uchinada, Ishikawa, Japan). 3 Dept. of Parasitology, Institute for Tropical Medicine, Nagasaki University, Nagasaki, Japan (Present address: Dept. of Internal Medicine, in same Institute).

This work is supported by research grant from Imperial Central Laboratory \& Research Institute, Ethiopia and the Overseas Technical Cooperation Agency of Japan. 
and cut at 5 to $8 \mu$. Slides from each were stained with hematoxylin and eosin. Skin snips from the same patients with microfilariae of $O$. volvulus were also sectioned for histo-pathological and comparative studies as described above.

\section{RESULTS}

Out of 10 inguinal lymph nodes surgically removed from subjects with onchocerciasis infection, 9 were positive for the larval filariae of $O$. volvulus. Lymph node material with microfilariae is shown in Figs. 1 and 2.

The criteria for the identification and differentiation of onchocercal microfilariae from those of other filarial spp. are described by the authors in another paper which is under preparation. The tissue section of the lymph nodes shows an extensive fibrosis entangling a large part of the medullary cords and a portion of peripheral lymphoid follicles with remarkable and wide obliteration of sinusoid spaces.

In the fibrotic lesion, blood capillaries are markedly congested and small arteries are surrounded by dense lamellar fibrosis known as "onion-skin" appearance. Diffuse infiltration of chronic inflammatory cells such as lymphocytes and plasma cells as well as eosinophiles and occasional multinucleated giant cells are seen. There are a considerable number of microfilariae embedded within the perivascular areas of the fibrotic lesion. The remaining part of the medulla being not severely collagenized reveals enlarged reticulum cells and many plasma cells. Lymphoid follicles show enlarged germinal centers.

Despite numerous microfilariae in the dermal tissue as seen in Figs. 3 and 4, no typical inflammatory reaction around the parasites is present. Perivascular lymphocytic infiltration is observed while eosinophiles are absent.

\section{Discussions}

Cohen (1960), Oomen (1969), Price (1972) and Heather and Price (1972) excluded the possibility of filarial etiology of elephantiasis in Ethiopia. They reported that both adult and larval filariae were absent from the areas investigated. Furthermore, Heather and Price (1972) reached the conclusion that silicates "play a significant part in establishing conditions favourable for the development of swollen leg, even possibly providing the trigger mechanism for the onset of filarial elephantiasis".

In contrast to the hypothesis quoted above, as indicated in Figs. 1 and 2, the present authors detected a number of onchocercal microfilariae in inguinal nodes. The extensive fibrosis, diffuse infiltration of lymphocytes, plasma cells, fairly large number of eosinophiles and multinucleated giant cells seem to be caused by the microfilarial invasion. In other words, the cellular reaction could be interpreted as a response to the parasitic infection. The absence of the inflammatory reaction of cellular elements in the dermal tissue around the microfilariae is also a common phenomenon in other filarial infections which is not yet clearly understood. Connor et al (1970) observed also only scattered eosinophilic leucocytes in the pretreated skin specimens.

There is a general consensus that the larval and adult stages of $O$. volvulus are only restricted to the dermal and subcutaneous tissue. The presence of numerous 
onchocercal microfilariae in the inguinal lymph nodes with and without clinical manifestations shows that this opinion needs a revision.

It is quite evident that the organisms migrate from the dermis and subcutis to the lymphatic system and cause histo-pathological changes described by other researchers (Connor et al, 1970) and present authors. The finding of microfilariae in the inguinal lymph node of a patient with scrotal elephantiasis indicates also the causal relationship between onchocerciasis and elephantiasis.

According to the anatomical landmarks of onchocercal microfilariae described by Iwamoto et al (1972), those of $W$. bancrofti are excluded in the present study. Furthermore, the examination of the peripheral blood taken by day and night interval gave also repeatedly negative results. It is worthwhile to note that McConnel (personal communication) recently found $W$. bancrofti infection in Gambella, one of the endemic foci of onchocerciasis. This finding, however, does not contradict the present one. Ouzilleau (1913), Dubois (1916) and Dubois and Forrow (1939) already reported elephantiasis of scrotum and legs in association with onchocerciasis. Sharp (1926) described also hydroceles, enlarged testes and lymphatic enlargement of thes crotum in patients infected with O. volvulus. Further, Connor et al (1970) reaffirmed the probable interaction between onchocerciasis and elephantiasis in Bussinga Ubangi territory of Zaire.

Our studies discussed above with those of previous authors suggest that $O$. volvulus could be regarded as one of the potential causative agents of elephantiasis in South-west Ethiopia, especially where onchocerciasis is mesoendemic.

We also do not deny that silicate particles observed in macrophages of inguinal nodes by Heather and Price (1972) might possibly cause elephantiasis, although we did not yet pay attention to the problems concerning the trace elements. In other words, nonfilarial elephantiasis in Ethiopia could not yet be excluded. We are also aware of the fact that detailed investigations such as lymphangiography and others should be performed in the near future before reaching a final conclusion that $O$. volvulus is the etiology of elephantiasis in the regions surveyed.

\section{Acknowledgements}

The present work would have been impossible without the help of many people. The authors express their deep gratitude to Dr. Solarov for removing the lymph nodes surgically. We are also indebted for reviewing the histo-pathological changes and comments to Dr. Tokuoka, Faculty of Medicine, Kagoshima University. The medical and paramedical personnels of Ras Desta Damtew Hospital deserve also our thanks.

\section{References}

1) Cohen, L. B. (1960): Idiopathic lymphoedema of Ethiopia and Kenya, East Afr. Med. J., 37, 53.

2) Connor, D. H., Morrison, N. E., Kerdel-Vegas, F., Berkoff, H. A., Johnson, F., Tunnicliffe, R., Failing, F. C., Hale, L. N., Lindquist, K., McCormick, J. B. and Anderson, S. L. (1970): On- 
chocerciasis: Onchocercal dermatitis, lymphadenitis and elephantiasis in the Ubangi Territory, Human Pathol., 1, 553-579

3) Dubois, A. (1916): Le rôle pathogĕne de O. volvulus Leuckart. Bull. Soc. Pathol. Exot., 9, 305

4) Dubois, A. and Forrow, M. (1939): Contribution à l'etude de l'elephantiasis Congolais. Le rôle de $O$. volvulus etudiě au Nepoko, Ann. Soc. Belge Med. Trop., 19, 13

5) Heather, C. J. and Price, E. W. (1972): Non-filarial elephantiasis in Ethiopia. Analytical study of inorganic material in lymph nodes, Tr. Roy. Soc. Trop. Med. Hyg., 66, 450-458

6) Iwamoto, I., Tada, I. and Wonde, T. (1972): Studies on onchocerciasis in Ilubabor Province, Ethiopia, Japan. J. Parasit., 21(Suppl.), 63

7) Oomen, A. P. (1969): Studies on onchocerciasis and elephantiasis in Ethiopia, Trop. geogr. Med., 21, 236

8) Ouzilleau, F. (1913): L'elephantiasis et les filarioses dans le M'Bonou (Haut-Oubangui): Rôle de la Filaria volvulus. Ann. Hyg. Méd. Colon, 16, 307-321 ; 16, 688-709

9) Ouzilleau, F. (1913): Les filaires humaines de la région du Mbomou (Afrique équatoriale française). Pathogenie de l'elephantiasis de cette région. Rôle de la Filaria volvulus, Bull. Soc. Path. Exot., 6, 80

10) Price, E. W. (1972): The pathology of non-filarial elephantiasis of the lower legs, Tr. Roy. Soc. Trop. Med. Hyg., 66, 150-159

11) Sharp, N. A. D. (1926): A contribution to the study of O. volvulus Leuckart, with some observations on its prevalence in Nigeria, Tr. Roy. Soc. Trop. Med. Hyg., 19, 373

12) Tada, I., Iwamoto, I. and Wonde, T. (1972): Studies on the emergence of Onchocerca volvulus microfilariae from skin snips, Japan. J. Parasit., 21(Suppl.), 65

エチオピア南西部における象皮病の一成因としてのオンコセルカ症

$$
\text { テフェラ・ウオンデ・・多田功・岩本功 }{ }^{3}
$$

エチオピア南西部には下肢象皮病患者が多く, その地域はまたオンコセルカ症の流行地でもある。従 来より像皮病の成因については種々の説があるが, 著者らは本症とオンコセルカとの関連を追求するた め，イルバボール州に住む下肢象皮病患者 10 名のそけい部リンパ節の組織学的検索を行をった。その 結果, 9 例のリンパ節につレてオンコセルカのマイクロフィラリアを見出した。更に, リンパ節にはマ イクロフィラリアないしはオンコセルカ感染に対するものと考えられる組織学的所見を認めた。こうし てリンパ系の閉塞が起こり，二次的に下肢の象皮病が成立したと考えうる所見であった。この結果から， 従来東アフリカの象皮病の成因について, 非フィラリア性のものとする説に対し, 再検討を要すると結 論する。

1 エチオピア帝国中央研究所 医動物学部門 2 鹿児島大学医学部 医動物学教室 3 長崎大学熱 帯医学研究所 寄生虫学部門 


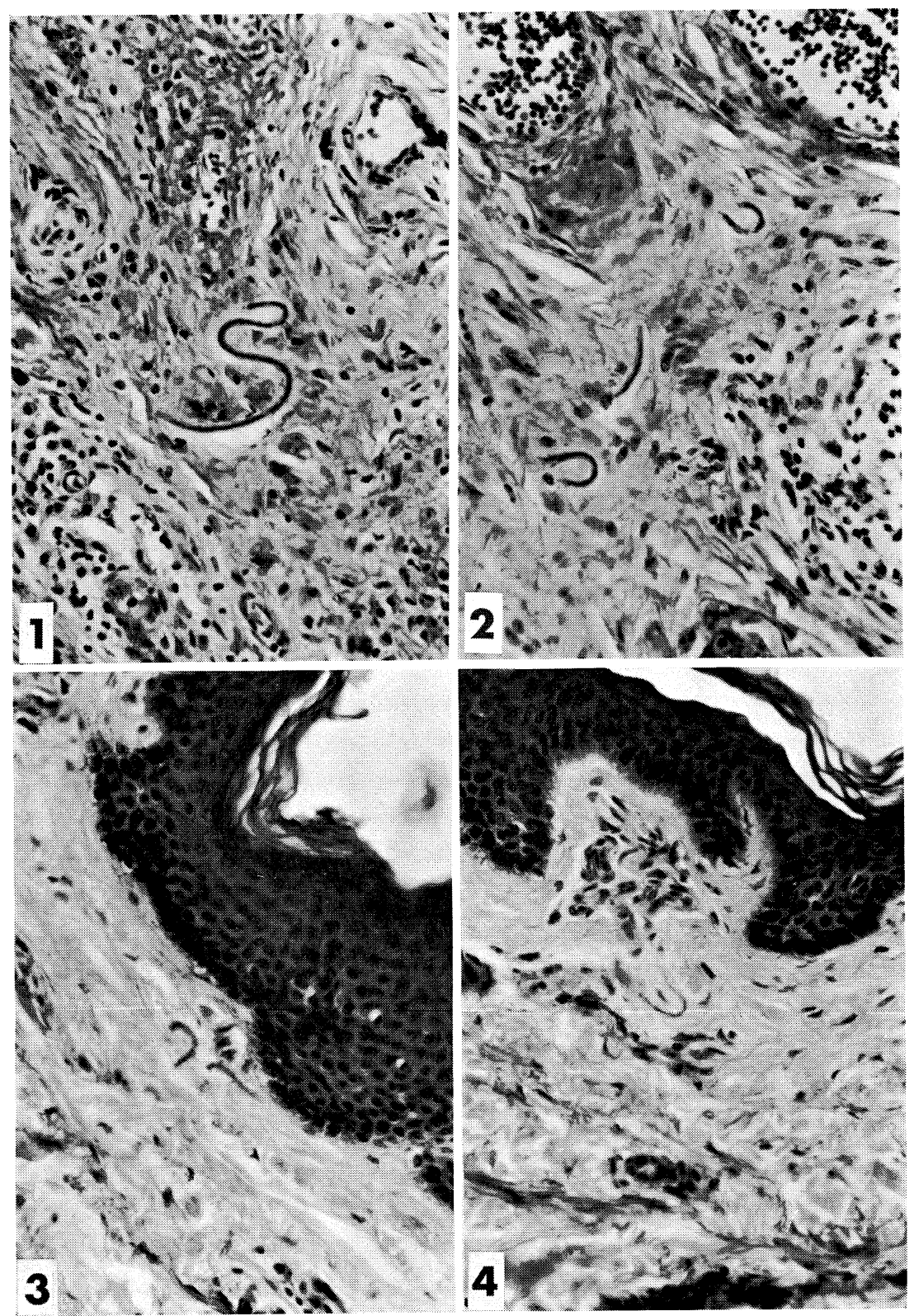

Fig. 1 and 2 Microfilariae shown in the inguinal lymphnodes from 2 elephantiasis patients (Abdella, Ilubabor Province, Ethiopia).

Fig. 3 and 4 Microfilariae shown in the dermal tissue from 2 onchocerciasis patients (Abdella, Ilubabor Province, Ethiopia). 